\title{
PROPOSAL FOR AN ERGONOMIC CONFORMITY INDEX FOR EVALUATION OF HARVESTERS AND FORWARDERS ${ }^{1}$
}

\author{
Felipe Leitão da Cunha Marzano ${ }^{2 *}$, Amaury Paulo de Souza ${ }^{3}$ and Luciano José Minette ${ }^{4}$.
}

\footnotetext{
${ }^{1}$ Received on 02.08.2016 accepted for publication on 24.03.2017.

${ }^{2}$ Universidade Federal de Viçosa,Programa de Pós-Graduação em Ciência Florestal,Viçosa,Minas Gerais,Brasil. E-mail: $<$ felipe.marzano@ufv.bf>.

${ }^{3}$ Universidade Federal de Viçosa,Departamento de Engenharia Florestal,Viçosa,Minas Gerais,Brasil. E-mail: <amaury@ufv.br>.

${ }^{4}$ Universidade Federal de Viçosa,Departamento de Engenharia de Produção e Mecânica,Viçosa,Minas Gerais,Brasil. E-mail: $<$ minette@ufv.br>.

*Corresponding author.
}

\begin{abstract}
Context: In mechanized forestry work, the ergonomic conditions of the workplace affects operator's health, performance and productivity. Originality: A comparison of different forest machines becomes complex in case where it is required analysis of several ergonomic factors simultaneously. There are several methods of ergonomic analysis however, a more complete methodology that considers several ergonomic factors and produces an index that represent the ergonomic condition of the machine is needed. Objective: Propose a methodology to determining an Ergonomic Conformity Index to evaluate Harvesters and Forwarders of different brands. Methodology: The ECI was determined initially basing in four relevant ergonomic factors: noise, vibration, thermal environment and air quality. These factors were evaluated utilizing four Harvesters and two Forwarders in eucalyptus timber harvesting operations. For each factor, a score was given according to its compliance with the established parameters. The ECI was obtained from an average of the scores given to each factor. The index ranges from zero to one, so that lower values indicate worse ergonomic conditions. Results: All the analyzed machines had continuous noise between 75.0 and $82.6 \mathrm{~dB}(\mathrm{~A})$ and whole-body vibration between 0.27 and $0.70 \mathrm{~m} \mathrm{~s}^{-2}$. HV1 and HV2 presented thermal environment in accordance with the established criteria, other machines showed deficiencies in this regard. All the machines presented non-conformities in the air quality, except HV2. The ECI of Harvesters HV1, HV2, HV3 and HV4, were $0.83 ; 0.88 ; 0.71 ; 0.63$. The ECI of Forwarders FW1 and FW2 were 0.58 and 0.79. Conclusion: The determination of the ECI allowed an evaluation and comparison between analyzed forest machines. The machine with the higher ECI had only one non-conformity, and it was related to noise inside the cab. The machine that got the lower ECI presented non-conformities for all the factors.
\end{abstract}

Keywords: Forest harvesting; Forest mechanization; Occupational hygiene

\section{ÍNDICE DE CONFORMIDADE ERGONÔMICA PARA MÁQUINAS FLORESTAIS}

\begin{abstract}
RESUMO - Contexto: No trabalho florestal mecanizado, as características ergonômicas do posto de trabalho influenciam a saúde, o desempenho e a produtividade dos trabalhadores. originalidade: A comparação entre diferentes máquinas florestais se torna complexa quando se deseja analisar diversos fatores ergonômicos simultaneamente. O Índice de Conformidade Ergonômica (ICE) proposto neste trabalho considera diversos fatores ergonômicos e permite uma comparação simples e objetiva entre máquinas florestais. Objetivo: Desenvolver metodologia para determinação do ICE e estabelecer uma comparação entre Harvesters $e$ Forwarders de diferentes marcas com o uso do ICE. Metodologia: O ICE foi determinado a partir da media de ICE parciais para ruído, vibração, ambiente térmico e qualidade do ar. Foi realizada avaliação desses fatores em quatro Harvesters $e$ dois Forwarders. Resultados: Todas as máquinas analisadas apresentaram ruído contínuo entre 75,0 e 82,6 dB(A) e vibração de corpo inteiro entre 0,27 e 0,70 $\mathrm{m} \mathrm{s}^{-2}$. Dois Harvesters apresentaram ambiente térmico em conformidade com os critérios estabelecidos, as demais máquinas apresentaram deficiências neste aspecto. Os ICE dos Harvsters HV1, HV2, HV3 e HV4 foram, respectivamente: 0,83; 0,88; 0, 71 e 0,63. Os ICE dos Forwarders FW1 e FW2 foram 0,58 e 0,79. Conclusão: A metodologia proposta se mostrou viável
\end{abstract}


para a comparação de máquinas florestais. A única não conformidade da máquina de maior ICE foi em relação ao ruído. A máquina que obteve menor ICE apresentou não conformidades para todos os fatores analisados.

Palavras-chave: Colheita florestal; Mecanização florestal; Higiene ocupacional.

\section{INTRODUCTION}

In the search for increased competitiveness in the global market, the mechanization of forest harvesting activities became a reality in Brazil. Forest machine operators remain exposed to adverse conditions such as noise, vibration and unfavorable thermal environment throughout the working day. Workers involved in these activities tend to extend their working hours or to compromise rest periods due to the constant need of machines maintenance and due to pressure for higher levels of production (Lilley et al., 2002).

The comfort of workers during the operation of forestry machines may have an important contribution to performance and productivity on work (Häggström and Lindroos O, 2016). In this sense, ergonomics has an important contribution to the sustainable development of work and of the corporations themselves (Bolis et al., 2014). Compliance with ergonomic principles in the development of modern forestry machinery should contribute to the reduction of mental and physical stress and other constraints imposed to the operator. In addition, it should contribute to reduce the probability of errors and the under-utilization of machines, with regard to their technical capabilities (Goscianska and Radniecki, 2009).

According to Gerasimov and Sokolov (2014), in terms of ergonomics, the best working conditions are offered by Harvesters and Forwarders. However, this system does not exempt workers from risks such as exposure to noise and vibration, poor thermal environment and poor air quality.

Noise is a complex mixture of several vibrations capable of sensitizing the human ear, understood as an auditory stimulus that does not contain useful information for the running task (lida, 2005). The main effect related to excessive noise exposure is NoiseInduced Hearing Loss (NIHL). Mechanisms involved in the development of this disease are not fully understood yet, but it is known that exposure to high doses of noise causes decreased blood flow and formation of free radicals in the cochlea (Le Prell et al., 2007). According to Fernandes and Morata (2002), even using Individual Protection Equipment, tractor operators presented PAIR, in addition to extra-auditory effects such as nervousness, anxiety, headache, tinnitus and stomach problems.

The use of adapted agricultural tractors is a reality in the forestry sector. Since most of these machines do not have a closed booth, the risks of exposure to noise and other environmental factors become even greater. According to Sumer et al. (2006), sound pressure levels in $4000 \mathrm{~Hz}$ range are up to $28 \mathrm{~dB}(\mathrm{~A})$ lower on closed cabin tractors when compared to tractors without cabs where noise has reached up to $90 \mathrm{~dB}(\mathrm{~A})$.

Vibration is an irregular movement that a body executes around a fixed point, being defined by frequency, acceleration and direction of the movement (lida, 2005). Exposure to full body vibration results from the presence of machines or vibrating agents in the work environment. This mechanical disturbance affects the physiological processes of the human body (Savage et al., 2016). The vibration and the adoption of inappropriate postures lead to a higher incidence of lumbar disorders among agricultural tractor operators than among unexposed workers (Bovenzi and Betta, 1994).

In the long term the exposed individuals can suffer adverse effects in the gastrointestinal and urogenital systems, in addition to the lumbar disorders (Wikstrom et al., 1994).

One of the intrinsic characteristics of forestry work is that workers are constantly exposed to climatic conditions. $\mathrm{n}$ the operation of forestry machines with enclosed cabins, the operator is more protected from external factors, however the work is not free of risks. Cabins that have large glass area can have a thermal behavior similar to greenhouses and concentrate the heat inside (Ruzic and Casnji, 2012). The consequences of the incidence of solar radiation on the skin can be acute, such as erythema or burn, thickening, elevation of temperature, tanning and immediate pigmentation; or chronic diseases such as photoaging or cancer (Schalka et al., 2014).

The presence of gases, dust and microorganisms in the air may be a source of illness for forest machine 
operators, as well as affect comfort conditions during operation.

In a study of the exposure of forest machine operators to these risk factors, Kallunki et al. (2004) have concluded that exposure under normal operating conditions is low as long as the cabin is kept closed and the filters are cleaned and replaced periodically.

The indexes are used as a way of comparison in the most diverse sectors, and its main advantage is the capacity of synthesis in comparisons involving several elements of a set, allowing even the monitoring of indicators over time. Indexes do not replace more detailed investigations and analyzes of reality, on the contrary, they are dependent on them in the aim of translate numerically certain phenomena by means of values that express a relative position with respect to a given point taken as a parameter (Vaitsman et al., 2003).

Ergonomic factors that influence the work in the forest sector have been analyzed by several authors (Bovenzi and Betta, 1994; Kallunki et al., 2004; Minette et al., 2007). However, studies contemplate each factor in isolation. The main objective of this work was to propose a methodology for the determination of an Ergonomic Conformity Index (ECI) for forest machines, considering the aspects related to exposure to noise, vibration, thermal environment and air quality. In addition, the secondary objective was to apply the proposed methodology in the ergonomic evaluation of Harvesters and Forwarders of different brands and models.

\section{MATERIALAND METHODS}

\subsection{Evaluated Forest Machines}

The methodology proposed in this work was applied in the evaluation of Harvesters and Forwarders. Harvesters from four different brands were evaluated, identified as HV1, HV2, HV3 and HV4 in this work. Forwarders from two different brands, identified as FW 1 and FW2, were also evaluated.

HV1 had 23,500 kg of weight, standard width of $3,180 \mathrm{~mm}$, with fuel tank volume of $5501,6 \times 6$ tires with $650 / 65 \times 26.5$ front tires and 700/70 x 34 rear tires. Engine was 6-cylinder with power of $210 \mathrm{~kW}(285 \mathrm{hp})$, torque of $1300 \mathrm{Nm}(1500 \mathrm{rpm})$ and $190 \mathrm{kN}$ traction force.

HV2 had an approximate weight of $20,000 \mathrm{~kg}$, a standard width of $3,085 \mathrm{~mm}$, with a fuel tank volume of 3801 rotated from $6 \times 6$ tires with $600 / 65-, 710 / 55$ 34 " front tires and rear tires of $800 / 40-26.5$ " . The engine was 6-cylinders with power of $205 \mathrm{~kW}(275 \mathrm{hp})$, torque of $1,100 \mathrm{Nm}$ (1200 to $1500 \mathrm{rpm})$ and $160 \mathrm{kN}$ traction force.

$\mathrm{HV} 3 \mathrm{had}$ an approximate weight of $21,000 \mathrm{~kg}$, standard width $3,090 \mathrm{~mm}$, with fuel tank volume of 350 1 and track system. The engine was 6-cylinder with power of $123 \mathrm{~kW}$ (165 hp), torque of $730 \mathrm{Nm}$ (1350 rpm) and $183 \mathrm{kN}$ traction force.

HV4 had an approximate weight of $21,000 \mathrm{~kg}$, a standard width of $2,900 \mathrm{~mm}$ and a track system with a maximum speed of $5.5 \mathrm{~km} / \mathrm{h}$. The engine was 6-cylinder with power of $155 \mathrm{hp}$ at $2000 \mathrm{rpm}$, and $178 \mathrm{kN}$ traction force.

FW1 had an approximate weight of $21,800 \mathrm{~kg}$, maximum load capacity of $18,000 \mathrm{~kg}$, standard width from 2,990 to $3,300 \mathrm{~mm}$, with fuel tank volume of 270 $1,8 \times 8$ tires, $750 / 55 \times 26,5$ tires. The engine was 6-cylinders with power of $205 \mathrm{~kW}(275 \mathrm{hp})$, torque of $1,100 \mathrm{Nm}$ (1200 to $1600 \mathrm{rpm}$ ) and $220 \mathrm{kN}$ of traction force.

FW2 had an approximate weight of $19,100 \mathrm{~kg}$, a maximum load capacity of $18,000 \mathrm{~kg}$, a standard width of 3,170 mm, a fuel tank volume of 210 liters, $8 \times 8$ tires, 750 / 45x30,5 tires. The engine was the CTA 74 CTA, 6-cylinder, turbocharged with Commonrail, with power of $170 \mathrm{~kW}(231 \mathrm{hp})$, torque of $100 \mathrm{Nm}$ at $1500 \mathrm{rpm}$ and $207 \mathrm{kN}$ of traction force.

\subsection{Ergonomic factors}

\subsubsection{Noise}

Continuous noise evaluation was done using a $01 \mathrm{~dB}$ Metravib Wed007 noise dosimeter brand operating in the "A" compensation circuit and slow response circuit. The measures were performed with the instrument fixed close to the workers ear, during the whole work shift. NR15 regulates the level of noise exposure for unhealthy purposes. For an 8-hour working day, the maximum set is $85 \mathrm{~dB}(\mathrm{~A})$ and the maximum allowed exposure time decreases progressively with increasing noise level. NR 17 regulates the level of noise exposure for the purpose of comfort in the workplace. In this case the maximum noise level for activities requiring intellectual solicitation and constant attention is $65 \mathrm{~dB}(\mathrm{~A})$.

Machines with equivalent noise levels equal to or greater than $65 \mathrm{~dB}(\mathrm{~A})$ received a non-compliance for this factor, so that the nonconformity value of $1(\mathrm{NC}=1)$ was assigned. For all machines that had 
equivalent noise levels between $65 \mathrm{~dB}(\mathrm{~A})$ and 85 $\mathrm{dB}(\mathrm{A})$, the value attributed to the Non-Conformity Weight was $0.5(\mathrm{NCW}=0.5)$. For machines that had an equivalent noise level of $85 \mathrm{~dB}$ (A), the value attributed to the Non-Conformity Weight was equal to $1(\mathrm{NCW}=1)$.

\subsubsection{Vibration}

The regulatory standard dealing with vibrationin Brazil is NR15, Annex 8, which specifies that if the daily occupational exposure limit of $1.1 \mathrm{~m} \mathrm{~s}^{-2}$ is exceeded work is considered unhealthy. In this case, preventive and corrective measures should be taken to preserve the health and safety of workers. According to Directive 2002/44 / EC of the European Community, the tolerance limit is equal to $1.15 \mathrm{~m} \mathrm{~s}^{-2}$ and the action level is equal to $0.5 \mathrm{~m} \mathrm{~s}^{-2}$.

The machines that presented an acceleration value resulting from normalized exposure (aren) equal to or greater than $0.5 \mathrm{~m} \mathrm{~s}^{-2}$ received a non-conformity for this factor, so that a non-conformity value of $1(\mathrm{NC}=1)$ was assigned. For all machines that presented an acceleration value resulting from normalized exposure (aren) between $0.5 \mathrm{~m} \mathrm{~s}^{-2}$ and 1.1 $\mathrm{m} \mathrm{s}^{-2}$ the value attributed to the Non-Conformity Weight was equal to $0.5(\mathrm{NCW}=0.5)$. For machines that had a standardized exposure (aren) acceleration value greater than or equal to $1.1 \mathrm{~m} \mathrm{~s}^{-2}$, the value attributed to the Non-Conformity Weight was equal to $1(\mathrm{NCW}=1)$.

The vibration evaluation was done using an 01dB-Stell Maestro accelerometer, in accordance with technical procedures established by the Occupational Hygiene Standard 09 (FUNDACENTRO, 2013). Whole body vibration levels were measured and in each case the resulting normalized exposure acceleration (aren) was obtained.

\subsubsection{Thermal environment}

The thermal environment inside the cabin was evaluated according to the parameters of the Ergonomic Checklist for Forest Machines (Almqvist R, Gellerstedt S, Tobish $\mathrm{R}, 2006$ ). The item "Cabins climate" was composed of 3 qualitative parameters.

The following aspects were analyzed: the ability to maintain adequate internal temperature even on hotter days; Uniform distribution of temperature and percentage of operator's body reached by incident sunlight. For each unattended parameter, a non-conformance value of $1 / 3$ (NC $=1$ ) was assigned, and the value assigned for the Non-

Revista Árvore. 2017;41(4):e410401
Conformity Weight was equal to 1 when it was a more severe non-compliance and $1 / 2$ when it is a mild non-compliance. The qualitative parameters for the evaluation of the thermal environment are shown in Table 1:

\subsubsection{Air quality}

The air quality inside the cabin was evaluated according to the parameters of the Ergonomic Checklist for Forest Machines (Almqvist etal., 2006). Three qualitative parameters were considered. For each unattended parameter, a nonconformance value of $1 / 3(\mathrm{NC}=1)$ was assigned. The value assigned for the Non-Conformity Weight was equal to 1 when it was a more severe non-compliance and $1 / 2$ when it is a mild non-compliance. The qualitative parameters for air quality evaluation are shown in Table 2:

\subsection{Ergonomic Conformity Index (ECI)}

The ergonomic factors considered in the determination of the Ergonomic Conformity Index (ECI) were the following: noise, vibration, thermal environment and air quality. All factors had the same weight in determining the Index. A Partial Ergonomics Conformity Index (ECIp) was calculated for each factor according to Equation 1, developed by the authors for this work.

$$
\mathrm{ECIp}=1-(\mathrm{NC} \times \mathrm{NCW})
$$

Where:

ECIp $=$ Partial Ergonomics Conformity Index

$\mathrm{NC}=$ Non-Compliance Assigned Value

NCW $=$ Non-Compliance Weight

The Ergonomic Conformity Index (ECI) was obtained from an arithmetic mean of the ECIp of all factors considered, according to Equation 2.

$$
\mathrm{ECI}=\frac{\mathrm{ECIr}+\mathrm{ECIv}+\mathrm{ECIt}+\mathrm{ECI} \mathrm{qa}}{4}
$$

Where:

ECIr $=$ Partial Ergonomic Conformity Index for noise

ECIv $=$ Partial Ergonomic Conformity Index for vibration

ECIat $=$ Partial Ergonomic Conformity Index for 
Table 1 - Qualitative parameters for forest machinesthermal environment evaluation.

Tabela 1 - Parâmetros qualitativos para avaliação de ambiente térmico em máquinas florestais.

\begin{tabular}{|c|c|}
\hline & Cabin temperature \\
\hline $\mathrm{C}$ & $\begin{array}{l}\text { Suitable temperature. In winter, adjustable between } 15 \text { and } 33^{\circ} \mathrm{C} \text { and in summer between } 20 \text { and } 25^{\circ} \mathrm{C} \text {. } \\
\text { These temperatures can be maintained in any weather or weather conditions. }\end{array}$ \\
\hline \multirow{3}{*}{$\begin{array}{l}\mathrm{NCW}=1 / 2 \\
\mathrm{NCW}=1\end{array}$} & Difficulty on maintaining proper temperature on hot summer days or cold wint \\
\hline & Difficulty on maintaining proper temperature in most situations \\
\hline & Uniformity of temperature \\
\hline \multirow[t]{2}{*}{$\begin{array}{l}\mathrm{NCW}=1 / 2 \\
\mathrm{NCW}=1\end{array}$} & $\begin{array}{c}\text { Temperature Uniformly distributed from head to feet of the operators. } \\
\text { The airflow is well distributed and does not cause discomfort. } \\
\text { Temperature differences in various parts of the body causing mild discomfort. } \\
\text { Clear differences in temperature between the various parts of the body. Inconvenient with drafts. }\end{array}$ \\
\hline & Sun protection \\
\hline $\begin{aligned} \mathrm{C} & \\
\mathrm{NCW} & =1 / 2 \\
\mathrm{NCW} & =1\end{aligned}$ & $\begin{array}{c}\text { Sunlight affecting a small area of the operator (up to } 10 \% \text { of the body, eg arms and hands). } \\
\text { Sunlight affecting to } 40 \% \text { of the body (eg chest, abdomen and thighs) } \\
\text { Sunlight on more than } 40 \% \text { of the operator's body. }\end{array}$ \\
\hline
\end{tabular}

Table 2 - Qualitative parameters for forest machinesair quality evaluation.

Tabela 2 - Parâmetros qualitativos para avaliação da qualidade do ar em máquinas florestais.

\begin{tabular}{|c|c|}
\hline Situation & Air filter \\
\hline $\mathrm{C}$ & $\begin{array}{l}\text { Filter system can remove dust, pollen and soot (quality at least F7). } \\
\text { There is a clear indication of when to replace the filter }\end{array}$ \\
\hline \multirow{3}{*}{$\begin{array}{l}\mathrm{NCW}=1 / 2 \\
\mathrm{NCW}=1\end{array}$} & Filter system at least F5. Indication of substitution with deficiencies. \\
\hline & No filter available or filter with poor function. Missing indication. \\
\hline & Replacing the filter \\
\hline $\begin{array}{c}\mathrm{C} \\
\mathrm{NCW}=1 / 2 \\
\mathrm{NCW}=1\end{array}$ & $\begin{array}{l}\text { Filter easily accessible and can be changed without the use of tools. } \\
\text { Easy access but tools are necessary. } \\
\text { Difficult to replace and tools are needed. }\end{array}$ \\
\hline $\mathrm{NCW}=1$ & \begin{tabular}{|l} 
Perception of the operator \\
\end{tabular} \\
\hline $\begin{array}{c}\mathrm{C} \\
\mathrm{NCW}=1 / 2 \\
\mathrm{NCW}=1\end{array}$ & $\begin{array}{l}\text { The operator does not smell any exhaust fumes and has no problem with dust or particles. } \\
\text { Under special conditions there may be momentary influence of exhaust fumes or dust. } \\
\text { There are obvious problems with exhaust fumes or dust. }\end{array}$ \\
\hline
\end{tabular}

thermal environment

ECIqa - Partial Ergonomic Conformity Index for air quality

A comparison of the ergonomic aspects of the forest machines was made by determining the ECI of each machine. According to the proposed methodology, machines with higher ECI are superior from the ergonomic point of view.

\section{RESULTS}

\subsection{Noise, Vibration, Thermal Environment and Air Quality}

The evaluation of the environmental agents during a typical work day allowed the determination of the Equivalent Noise Level(LAEq), the resulting acceleration of standardized exposure (aren) and the qualitative aspects related to the thermal environment and the air quality inside the cabs of the forest machines analyzed. The results of the evaluations and the respective Partial Ergonomic Conformity Indices are presented in Table 3.

\subsection{Ergonomic Conformity Index (ECI)}

The determination of ECI allowed a comparison between the analyzed forest machines. The ECI of Harvesters HV1, HV2, HV3 and HV4 were, respectively: 0.83; 0.88; 0.71 and 0.63 . The ECI of Forwarders FW 1 and FW2 were 0.58 and 0.79 .

\section{DISCUSSION}

Continuous noise levels varied between 75.0 and 82.6 $\mathrm{dB}$ (A). All the analyzed machines obtained the ECIr equal

Revista Árvore. 2017;41(4):e410401 
Table 3 - Equivalent noise level (LAEq),resulting acceleration of standard exposure (aren), thermal environment, air quality and partial Ergonomic Compliance Indices of Harvesters and Forwarders.

Tabela 3 - Nivel de ruído equivalente ( $L A E q$ ), aceleração resultante da exposição normalizada(aren), ambiente térmico, qualidade do ar e Índices de Conformidade Ergonômica parciais de Harvesters e Forwarders.

\begin{tabular}{|c|c|c|c|c|c|c|c|}
\hline \multicolumn{2}{|c|}{ MACHINE } & HV1 & HV2 & HV3 & HV4 & FW1 & FW2 \\
\hline \multirow{4}{*}{ Noise } & $\mathrm{dB}(\mathrm{A})$ & 77,4 & 78,6 & 76,2 & 78,9 & 75,0 & 82,6 \\
\hline & $\mathrm{NC}$ & 1 & 1 & 1 & 1 & 1 & 1 \\
\hline & NCW & $1 / 2$ & $1 / 2$ & $1 / 2$ & $1 / 2$ & $1 / 2$ & $1 / 2$ \\
\hline & ECIr & 0,5 & 0,5 & 0,5 & 0,5 & 0,5 & 0,5 \\
\hline \multirow{4}{*}{ Vibration } & $\mathrm{m} \mathrm{s}^{-2}$ & 0,33 & 0,37 & 0,37 & 0,27 & 0,70 & 0,38 \\
\hline & $\mathrm{NC}$ & 0 & 0 & 0 & 0 & 1 & 0 \\
\hline & NCW & - & - & - & - & $1 / 2$ & - \\
\hline & ECIv & 1 & 1 & 1 & 1 & 0,5 & 1 \\
\hline \multirow{3}{*}{$\begin{array}{l}\text { Thermal } \\
\text { Environment }\end{array}$} & $\mathrm{NC}$ & 0 & 0 & $1 / 3$ & $2 / 3$ & $1 / 3$ & $1 / 3$ \\
\hline & NCW & - & - & $1 / 2$ & $1 / 2$ & $1 / 2$ & $1 / 2$ \\
\hline & ECIat & 1 & 1 & $5 / 6$ & $4 / 6$ & $5 / 6$ & $5 / 6$ \\
\hline \multirow{3}{*}{ Air quality } & $\mathrm{NC}$ & $1 / 3$ & 0 & 1 & 1 & 1 & 1 \\
\hline & NCW & $1 / 2$ & - & $3 / 6$ & $4 / 6$ & $3 / 6$ & $1 / 6$ \\
\hline & ECIqa & $5 / 6$ & $\mathbf{1}$ & $3 / 6$ & $2 / 6$ & $3 / 6$ & $5 / 6$ \\
\hline
\end{tabular}

to 0.5 . This indicates that the values found are below the limit of exposure allowed by Brazilian legislation, which is $85 \mathrm{~dB}(\mathrm{~A})$ for an 8-hour daily exposure, but above the comfort threshold, which is $65 \mathrm{~dB}$ (A). Similar results are described by other authors in studies carried out with the same types of machines analyzed in this study (Messingerová et al., 2005; Minette et al., 2007). Under these working conditions, the operator may have a reduction on productivity and performance, as well as the risk of hearing loss and extra-auditory effects.

The vibration levels to which workers were exposed ranged from 0.27 to $0.70 \mathrm{~m} \mathrm{~s}^{-2}$. All analyzed Harvesters had a lower vibration value than the action level proposed by the European Community Directive 2002/44 / EC and only FW1 showed vibration above $0.50 \mathrm{~m} \mathrm{~s}^{-2}$.

These values were similar to those found by Jankovský et al. (2016). The high vibration value caused the FW1 to obtain the lowest ECI between the analyzed machines. Vibration reductio $^{n}$ depends on engineering measures, such as the suspensions studied by Fleury e Mistrot (2006).

All factors related to the thermal environment in HV1 and HV2 were in accordance with the determined standards.

In HV3 it was found that there was higher heating in the operator's legs region. In HV4, in addition to the temperature being not uniform throughout the cabin, there was a high incidence of sunlight on the operator's body. In FW1 there was an incidence of sunlight up to $40 \%$ of the body of the operator and in FW2 the cooling system was not able to maintain the proper temperature on the hottest days.

The only machine that was in compliance with all air quality parameters was HV2. In the HV1 the air filtering system had deficiencies. In the HV3 and in the FW1 all the items presented slight nonconformities. In the HV4 it was verified influence of the exhaust gases and dust during part of the operation and in the FW2 the change of the filter was only possible using specific tools.

The forest machines that obtained higher ECI were HV1 and HV2. The differential in these machines was the low vibration level and the favorable thermal environment inside the cab. The machine that obtained the best ECI, the HV1, showed only one nonconformity, related to the noise. To obtain the maximum ECI equal to 1 , the noise in this machine should be less than $65 \mathrm{~dB}$ (A).

The ECI proposed in this work allowed a simple and direct ergonomic evaluation of forest machines. It was possible to establish a comparison between the forest machines evaluated, by determining the ECI of each one of them.

Although the index represents a simple and direct comparison, a partial indexes analysis can provide more detailed information on the items responsible for the final ECI value. The ECI model may have other variables included. Among these variables, the aspects related to repetitiveness, work posture and cabin dimensions. 
On this work, the proposed ECI was applied in the evaluation of Harvesters and Forwarders. However, the same methodology could be applied in the ergonomic evaluation of other forest machines, such as Feller-Bunchers or Skidders.

\section{CONCLUSIONS}

The methodology proposed on this work to determine the Ergonomic Conformity Index (ECI) was efficient in the ergonomic evaluation of harvesters and forwarders. The determination of the ECI of the evaluated machines allowed the establishment of a comparison between them. The descending ECI order of evaluated harvesters was: HV2, HV1, HV3, HV4. The FW2 forwarder obtained higher ECI than FW1.

All evaluated forest machines had a continuous noise level above $65 \mathrm{~dB}(\mathrm{~A})$, which is the limit established for comfort purposes, but less than $85 \mathrm{~dB}$ (A), occupational exposure limit for unhealthy purposes. Only the FW1 had a full body vibration level above the action level. Only HV1 and HV2 presented thermal environment in accordance withall the qualitative criteria used in the evaluation. Air quality inside the cab was considered unsatisfactory for all evaluated machines, except for $\mathrm{HV} 2$

\section{REFERENCES}

Almqvist R, Gellerstedt S, Tobish R. Ergonomic checklist for forest machines. Uppsala, Sweden: Swedish University of Agricultural Sciences; 2006.

Bolis I, Brunoro CM, Sznelwar LI. Mapping the relationships between work and sustainability and the opportunities for ergonomic action. Applied Ergonomics, 2014; 45:1225-39.

Bovenzi M, Betta A. Low-back disorders in agricultural tractor drivers exposed to whole body vibration and postural stress. Applied Ergonomics, $1994 ; 25: 231-41$

European Comission. Directive 2002/44/EC of the European Parliament and of the Council of 25 June 2002 on the minimum health and safety requirements regarding the exposure of workers to the risks arising from physical agents (vibration). Official Journal of the European Communities. 1. 177/13:2002.

Fernandes M, Morata TC. Estudo dos efeitos auditivos e extra auditivos da exposição ocupacional a ruído e vibração. Revista Brasileira de Otorrinolaringologia. 2002; 68(5):715-3.

Fleury G, Mistrot P. Numerical assessment of foreand-aft suspension performance to reduce whole-body vibration of wheel loader drivers. Journal of Sound and Vibration. 2006; 298:672-687.

FUNDACENTRO. Norma de Higiene Ocupacional: NHO 09: avaliação da exposição ocupacional de corpo inteiro: procedimento técnico. São Paulo: FUNDACENTRO, 2013.

Gerasimov Y, Sokolov A. Ergonomic evaluation and comparison of wood harvesting systems in Northwest Russia. Applied Ergonomics, 2014;45;318-38.

Häggström C, Lindroos O. Human, technology, organization and environment - a human factors perspective on performance in forest harvesting. International Journal of Forest Engineering. 2016;27(2):67-78.

Iida I. Ergonomia: Projeto e produção. São Paulo: Edgar Blucher; 2005.

Jankovský M, Messingerová V, Ferenèík M, Allman M. Objective and subjective assessment of selected factors of the work environment of forest harvesters and forwarders. Journal of Forest Science, 2016;62(1);8-16.

Le Prell CG, Yamashita D, Minami SB, Yamasoba T, Miller JM. Mechanisms of noise-induced hearing loss indicate multiple methods of prevention. Hearing Research, 2007;226:22-43.

Lilley R, Feyer AM, Kirk P, Gander P. A survey of forest workers in New Zealand. Do hours of work, rest, and recovery play a role in accidents and injury? Journal of Safety Research, 2002;33;53-71.

Kallunki H, Makinen M, Ojanen K, Laitinen S, Kangas J. Exposure to biological fungicides, environmental microorganisms and oils in forestry harvesting. Scandinavian Journal of Forestry Research, 2004;19:82-8. 
Messingerová V, Martinusová L, Slancik M. Ergonomic parameters of the work of integrated technologies at timber harvesting. Croatian Journal of Forest Engineering. 2005;26(2):79-84.

Minette LJ, Silva EP, Souza AP, Silva KR. Avaliação dos níveis de ruído, luz e calor em máquinas de colheita florestal. Revista Brasileira de Engenharia Agrícola e Ambiental. 2007;11(6):664-7.

Ruzic D, Casnji F. Thermal interaction between a human body and a vehicle cabin. In: Heat transfer phenomena and applications. Novi Sad, Servia: InTech; 2012.

Savage R, Billing D, Furnell A, Netto K, Aisbett D. Whole body vibration and occupational physical performance: a review. International Archives of Occupational and Environmental
Health. 2016;89:181-97.

Schalka S, Steiner D, Ravelli FN, Steiner T, Terena AC, Marçon CR. Consenso Brasileiro de Fotoproteção. Anais Brasileiros de Dermatologia. 2014;89(6):6-75.

Sümer SK, Say SM, Ege F, Sabanci A. Noise exposed of the operators of combine harvesters with and without a cab. Applied Ergonomics, 2006;37;749-56.

Vaitsman J, Farias LO, Mattos AM, Campos Filho AC. Metodologia de elaboração do índice de percepções organizacionais. Caderno de Saúde Pública do Rio de Janeiro. 2003;19(6):1631-43.

Wikstrom B, Kjelberg A, Landstrom U. Health effects of long-term occupational exposure to whole-body vibration: A review. International Journal of Industrial Ergonomics. 1994;14:273-92. 